\title{
Diversity and Abundance of Orchids at Gebugan Nature Reserve in Semarang, Indonesia
}

\author{
Tria Farokhah, ${ }^{\bowtie}$ Sri Utami, Jumari \\ DOI: http://dx.doi.org/10.15294/biosaintifika.v10i2.14579
}

Departement of Biologi, Faculty of Science dan Mathematics, Universitas Diponegoro, Indonesia

\section{History Article \\ Received 6 May 2018 Approved 12 July 2018 Published 30 August 2018}

\section{Keywords}

Abundance of species; Gebugan Nature Reserve; Orchid diversity

\begin{abstract}
Orchid is a plant with a high aesthetic value. The existence of orchids directly by the community from their natural habitat, causing the existence of orchid in nature was threatened. The potential of orchid diversity in the Gebugan Nature Reserve area needs exploration to maintain its sustainability. This research would explore the diversity and abundance of orchid species and determined the environmental conditionof Gebugan Nature Reserve. The study was done on 2 stations with altitude difference are $900 \mathrm{~m}$ asl and $1045 \mathrm{~m}$ asl. Five plots of $10 \mathrm{~m} \mathrm{x} 10 \mathrm{~m}$ were systematically constructed at each station with a distance of plots 50 meters. Species of orchids found in the Gebugan Nature Reserve were 12 species, including 11 species of epiphytic orchids and 1 species of terrestrial orchids. The abundance of individual orchid species was relatively higher in places with higher altitudes. Micropera sp was the most abundant orchid species and Corymborkis veratrifolia was the species of orchid with the lowest abundance. It is found that the environmental conditions of Gebugan Nature Reserve are suitable for orchid. The novelty of the research is providing a new data base of orchid in the Gebugan Nature Reserve. The result of the study would be beneficial for developing strategy of genetic conservation of orchird germplasm.
\end{abstract}

\section{How to Cite}

Farokhah, T., Utami, S., \& Jumari. (2018). Diversity and Abundance of Orchids at Gebugan Nature Reserve in Semarang, Indonesia. Biosaintifika: Journal of Biology \& Biology Education, 10(2), 284-290.

(C) 2018 Universitas Negeri Semarang $\bowtie$ Correspondence Author:

Jl. Prof. H. Soedarto, SH, Tembalang, Semarang

E-mail: utami.biologi@gmail.com
p-ISSN 2085-191X

e-ISSN 2338-7610 


\section{INTRODUCTION}

Orchids are one of the largest and most diverse flowering plant families, and are widespread throughout the world except in dry and cold regions. Most orchids are found in humid tropics and it is estimated that there are approximately 25,000 species in the world (Kartikaningrum \& Suskandari, 2004).

According to Tahier et al. (2012), orchids are ornamental plants that have high aesthetic value. The shape and color of orchids and other unique characteristics become the main attraction,so many people are interested to collect orchids as ornamental plants. This great potential is a distinct advantage for our country, but it is also a challenge to maintain, manage and preserve it. Orchids exploration by human from their natural habitat, threathens the existence of orchids in nature. Conservation areas such as national parks, ecotourism parks, wildlife sanctuaries and nature reserves are natural growing sites and dispersal areas of most flora in Indonesia (Test, 2005). One of the conservation areas in Semarang Regency is Gebugan Nature Reserve. The area of Gebugan Nature Reserve, Semarang is about $1.8 \mathrm{Ha}$. It is located on the slopes of Mount Ungaran with the altitude of about 1,050 meters above sea level with hilly and bumpy topography. It has latosol (inceptisol) yellowish brown type of soil. The average rainfall is $2,000 \mathrm{~mm} /$ year with temperatures between $18-26.8^{\circ} \mathrm{C}$ The type of its ecosystem is highland tropical rain forest (BKSDA Jawa Tengah, 2009).

Research on the diversity of orchid species has been done, among others, the colonization of orchid species in Krakatau Island (Partomihardjo, 2003), the relationship between the existence of moss plants (Bryophyta) and the growth and continuity of Lepanthes spp. (Crain, 2012), the diversity of Orchidaceae species in the Protected Forest Area in Talang Mountain of West Sumatra (Musa et al., 2013) and the diversity of orchids in the Bangka Belitung Islands (Destri et al., 2015). But research on the diversity and abundance of orchid species in protected forest Gebugan Semarang Central Java has never been done. Therefore, it is necessary to conduct a study on the diversity of orchidsin Gebugan nature reserve, Semarang.

Limited information on the species of orchids in the area of Nature Reserve Gebugan made researchers interested to explore and seek the potential of existing orchid diversity to keep its sustainability. The purpose of this study was to explore diversity and abundance of orchid species and determine the environmental conditions in Gebugan Nature Reserve.

The benefits of the result would be for developing strategy of genetic conservation of orchird germplasm.

\section{METHODS}

The research was conducted from June to November 2017 in Gebugan Semarang Regency (Figure1). Orchids identification was conducted in the Laboratory of Ecology and Biosistematics, Departement of Biology, Faculty of Science and Mathematics, Diponegoro University.

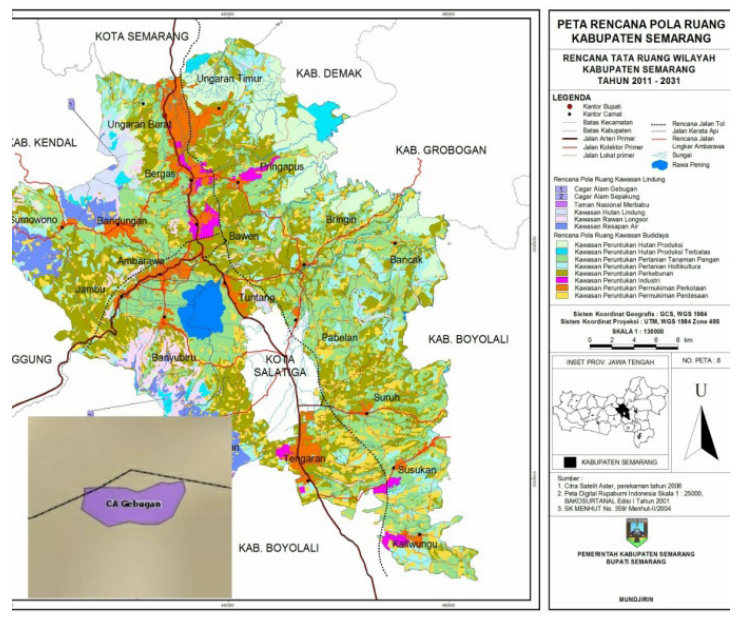

Figure 1. Research location map

The tools used in this research were camera, note book, stationery, knife, scissors, sample bag, altimeter, GPS, label, luxmeter, ruler, tweezers, plastic rope, thermometer, hygrometer and identification book.

Materials used in the study were orchids and Alcohol 70\%. Pre-survey was aimed to determine the condition of Gebugan Nature Reserve Semarang Regency and determine the research station. The result of this pre-survey determined two observation stations that have different altitude which was Station 1: $900 \mathrm{~m}$ asl and Station 2: $1045 \mathrm{~m}$ asl.

Sampling was conducted by using quadratic plot and the plotting was done systematically. Sampling began with a 300-meter long transect at the first point at the edge of the research site. From the transect line were then made each of 5 plots measuring $10 \times 10$ meters with the distance of each plot was 50 meters.

The orchids species found in each plot were identified and counted by the number of individuals. Each species of orchid was recorded in a collection book composed of the species name, 
types (epiphytes or terrestrial), host tree species and orchid location on the host tree. Unknown species are further identified in the laboratory. Each orchid found later was documented using a camera. Unidentified orchids were then identified in the Laboratory of Ecology and Biosystematics Department of Biology using Orchids of Java as identification books.

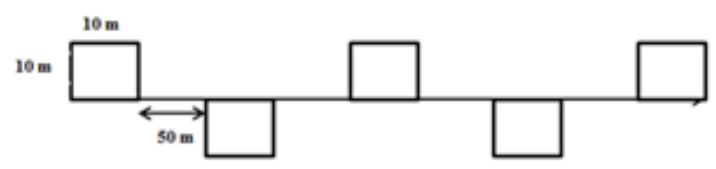

Figure 2. Sampling plot model.

At each station, the measurement of environmental factors including:altitude, ambient temperature, humidity and light intensity.Data on the diversity of orchid species are tabulated and analyzed descriptively by looking at the characteristics of each species. Two calculations were performed, namely absolute abundance and relative abundance. The absolute abundance of each type of orchid in each station was calculated using the following formula.(Krebs, 1972).

$$
A=\frac{\text { Einativiatualspeciesi }}{\text { sampleplotarea }}
$$

As for calculating relative abundance was calculated using the following formula (Krebs, 1972).

$$
R A=\frac{\Sigma \text { individual species } i}{\Sigma \text { total individual }} \times 100 \%
$$

\section{RESULTS AND DISCUSSION}

Orchids Diversity

Based on the research that has been conducted in the Gebugan Nature Reserve, as many as 12 species included in the 8 genera were found. The variety of orchid species in Gebugan Nature Reserve can be seen in Table 1.

Based on the results obtained, epiphytic orchids were found consisting of genus Liparis, Pholidota, Coelogyne, Bulbophyllum, Eria, Phreatia, Dendrochilum, Dendrobium, Ceratostylis and Micropera. Thespecies of orchids found have certain morphological characteristics that characterize each species. The number of epiphytic orchids found in the study sites was influenced by the intensity of light. Epiphytic plants like a bright light to grow as epiphytic plants attached to the host tree (Dressler, 1982). The epiphytic nature of epiphytic orchids attached to other plants is one of the adaptation ways to obtain sunlight (Tirta et al., 2010). Epiphytic plants of the Orchidaceae tribe are easy to find, rich in species, scattered, and most abundant compared to other plants (nails, lichenes, etc.) (Partomihardja, 1991). There was found 1 species of terrestrial orchid Corymborkis veratrifolia (Figure 3c)Terrestrial orchid plants tend to favor shade and grow on the forest floor (Dressler, 1982). The existence of terrestrial orchids found only 1 species caused by environmental conditions of the nature reserve which only has the height of $1050 \mathrm{~m}$ above sea level. The terrestrial orchids is common lyat altitudes above 2000 meters (Jacquemyn et al., 2007).

There were 7 species of host trees boarded

Tabel 1. Orchid Diversity in The Gebugan Nature Reserve

\begin{tabular}{lll}
\hline Species Name & Type & Habitat/Host Tree \\
\hline Bulbophyllumsp & Epiphyte & Castanopsis argentean \\
Coelogyneminiata (Blume) Lindl. & Epiphyte & Castanopsis argenteaLithocarpus sundaica \\
Ceratostylis sp & Epiphyte & Uncaria gambir, Palaquium rostratum \\
Corymborkis veratrifolia (Reinw.) Blume & Terrestrial & Soil \\
Dendrobium sp & Epiphyte & Lithocarpus sundaica \\
Dendrochilum sp & Epiphyte & Pongamia pinnata \\
Eria sp & Epiphyte & Palaquium rostratum, Castanopsis argentea, Lith- \\
& & ocarpus sundaica \\
Micropera sp & Epiphyte & Pongamia pinnataLithocarpus sundaica, Uncaria \\
Liparis sp & Eambir \\
Pholidotae sp & Epiphyte & Castanopsis argentea \\
Phreatia laxiflora(Blume) Lindl. & Epiphyte & Uncaria gambir \\
Phreatia sp & Epiphyte & Macaranga tanarius \\
\hline
\end{tabular}


by orchids (Table 1). Based on Table 1, some species of orchids cannot only grow on one particular host species but could also grow in different hosts. But some species of orchids were also found only in one type of hosts such as Eria sp., Dendrochilum $s p$, Dendrobium sp, and Phreatia laxiflora. The host for epiphytic orchids is one of the fundamental needs in getting better light and air circulation. This causes some species of orchids to choose a particular host to grow. But orchids do not always have a specific relationship with their host (Puspaningtyas, 2005). Orchids can stick to trees that able to create a microclimate and an environment suitable for growth regarding light intensity, air movement, temperature and humidity (Puspitaningtyas, 2007). In the Gebugan Nature Reserve, the tree with the majority of epiphytic orchids was Castanopsis argentea tree. This tree is also known in the area of Gebugan Nature Reserve as the Sarangan tree. Another local name for this tree species is the Saninten tree. Castanopsis argentea is found in primary or old secondary forest, usually on dry, fertile soils, at an altitude of 150$1750 \mathrm{mdpl}$ in certain places in Java, this species is dominant (Lemmens et al., 1995). General characteristics of Sarangan tree are its textured skin rather rough and uneven and it has a gray-brown wood to reddish brown (Martawijaya et al., 1989). Orchids tend to grow on rough-skinned host that can hold more litter than slippery trees. Generally hollow and soft leather with rough surfaces will retain better water, and gaps allow the orchid seed to become easily caught. Meanwhile, the slippery bark will complicate the litter or litter of orchid plants and orchids. Water can not is stuck for long because it will quickly flow and evaporate dry (Whitner, 1974).

Orchid Micropera $s p$. was the species that founded cling to most different tree species (Table 1). All species generally as host or attachment of orchids because the tree is the original habitat (Bahari, 2010). Therefore it is possible if one species of orchids can live on more than one species of tree. Orchid only use its host as a place to attach themselves and buffer to breathe the air but the orchid is not a parasite. Therefore, orchids can grow on both live and dead trees (Badu, 2013).
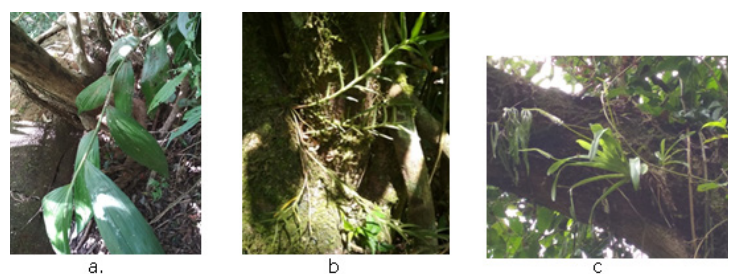

Figure 3. a. Micropera $s p$; b. Phreatia laxiflora $c$, Corymborkis veratrifolia

Based on the research that has been done in Gebugan Nature Reserve, there are differences in the number of species and the number of individuals in both research stations. The following is more information presented in Table 2.

Based on Table 2, there was a difference between the number of species of orchids and the number of individuals in both stations. Some species of orchid found in station 1 fewer with 8 species whereas in station 2 there was more with 10 species of orchid. It could be seen that the altitude affects species diversity and the number of individual orchids, although the altitude differ-

Tabel 2. The abundance of Orchid Species

\begin{tabular}{lcccc}
\hline \multirow{2}{*}{ Orchid Species } & \multicolumn{2}{c}{ Station 1} & \multicolumn{2}{c}{ Station 2} \\
\cline { 2 - 5 } & Individual /ha & AR \% & Individual /ha & AR \% \\
\hline Bulbophyllum sp & 40 & 8.3 & 40 & 4.5 \\
Ceratostylis sp & 40 & 8.3 & 40 & 4.5 \\
Coelogyne miniata & 40 & $8 ., 3$ & 100 & 11.4 \\
Corymborkis veratrifolia & 20 & $4 ., 2$ & - & - \\
Dendrobium sp & - & - & 20 & 2.8 \\
Dendrochilum sp & - & - & 120 & 13.6 \\
Eria sp & 80 & 16.7 & 100 & 11.4 \\
Liparis sp & 40 & 8.3 & 20 & 2.8 \\
Micropera sp & 140 & 29.2 & 100 & 11.4 \\
Pholidota $\mathrm{sp}$ & 80 & 16.7 & - & - \\
Phreatia laxiflora & - & - & 160 & 18.2 \\
Phreatia $\mathrm{sp}$ & - & - & 180 & 20.4 \\
$\sum$ & 480 & & 880 & \\
\hline
\end{tabular}


ence between the two stations is not very large. These altitude differences cause the environmental conditions underlying the growth of orchids were also different (Table 3). Differences in the altitude will affect the state of the environment of plants, especially temperature, humidity, sunlight intensity so that environmental conditions grow that affect growth (Tahier et al., 2012). From low to moderate $(0-1500 \mathrm{~m}$ asl $)$ the number of orchids is directly proportional to the altitude. The higher altitude the higher the species diversity (Jacquemyn et al., 2007).

The absolute abundance at station 2 was higher with 880 individuals/hectares while at station 1 with 440 individuals / hectares. It was related to the number of species and the number of individual orchids that were more numerous in station 2. Environmental conditions that are suitable to grow as the needs of light, moisture fulfilled affect the orchid to grow well. Good growth then affects the number of individuals of each species as well. Differences in environmental conditions such as sunlight, humidity and altitude supported by the ability of adaptation of species and surrounding tree vegetation can lead to varied micro climates so that a determinant factor of an orchid species can live normal and reproduce (Chikmawati, 1994). Relative abundance or density is the percentage of individual species in the community. Relative abundance values are classified into three categories: high $(>20 \%)$, moderate $(15 \%-20 \%)$, and low $(<15 \%)$ (Krebs, 1989). Based on Table 6, of the 12 species found 2 species of orchidsare in the category of high abundance $(>20 \%)$ ie Micropera $s p$ (Figure $3 a)$ and Phreatia $s p$. (Figure $3 b$ ). The moderate abundance category $(15 \%-20 \%)$ were Eria $s p$, Pholidota sp and Phreatia laxiflora. While the low abundance category $(<15 \%)$ were Bulbphyllum $s p$, Ceratostylis sp, Ceologyne miniata, Corymborkis veratrifolia, Dendrobium sp, Dendrochilum sp and Liparis $s p$. The most abundant species among all orchids found was Micropera $s p$. This was because the appropriate environmental conditions to grow and Micropera $s p$ is easy to adapt to the surrounding environment. The orchid was found to be growing on 3 different host trees (Table 3). This species of orchid is one type of epiphytic orchid that likes an open habitat with high sunlight intensity and often found clustered (Comber, 1990). Spreading orchids are widely assumed to have higher environmental adaptability (Priandana, 2007).

The abundance of orchid species is highly dependent on environmental factors. If environmental factors such as temperature, sunlight intensity, humidity and nutrients do not meetthe needs of each type of orchid, the orchid cannot grow and develop in its habitat well (Yulia, 2010).

Environmental Condition of Gebugan Nature Reserve

As the supporting data, the measurement of environmental factors such as altitude, temperature or air temperature, air humidity, and light intensity had been conducted. Measurements of environmental conditions carried out during the day, with the time range from 10:00 to $14: 00 \mathrm{pm}$. The results of the light intensity and humidity parameters were obtained by averaging the measurements of each plot. The result of measurement of the environmental condition of Gebugan Nature Reserve can be seen in Table 3 as follows.

Tabel 3. Environment factor Gebugan Nature Reserve

\begin{tabular}{lcc}
\hline Parameter & Station I & Station II \\
\hline Light Intensity(lux) & 2032 & 1720 \\
Humidity\% & 76.2 & 78.2 \\
Heightm asl & 900 & 1045 \\
Temperature $^{\circ} \mathrm{C}$ & 27.5 & 27.0 \\
\hline
\end{tabular}

Based on the conducted measurement, the environmental factors measurement results from both stations did not have a striking difference of ecological factors. Air humidity in both stations were $76.2 \%$ and $78.2 \%$, respectively, indicated suitable conditions for growing orchids. Orchids require ideal air humidity for life ranging from $60 \%$ - 85\% (Prastowo et al., 2006).

Based on Table 5, the temperature measurement results obtained $27^{\circ} \mathrm{C}-27.5^{\circ} \mathrm{C}$. The temperature difference between the two stations was only a slight number because both stations were still in the same neighborhood. The ideal environment for orchid growth is an average air temperature of $25^{\circ} \mathrm{C}-27^{\circ} \mathrm{C}$, with a minimum air temperature of $21^{\circ} \mathrm{C}-23^{\circ} \mathrm{C}$ and a maximum of $31^{\circ} \mathrm{C}-34^{\circ} \mathrm{C}$. Daytime temperature is $27^{\circ} \mathrm{C}-32^{\circ} \mathrm{C}$ and at night ranges from $21^{\circ} \mathrm{C}-24^{\circ} \mathrm{C}$ (Sutiyoso, 2009).

Measurement of light intensity produces light needs of 1720 lux and 2032 lux at stations 1 and 2. Light intensity need of each type of orchid is varied. There are several categories of orchids that require direct irradiation (5000 lux), bright light (3000 - 5000 lux), medium (2000 - 3000 lux), shade (1000 - 2000 lux) (Jacquemyn et al., 2007).

Measurement of altitude taken in this research was 900 - 1045 meters above sea level. Approximately $90 \%$ of orchids in Java grow in areas with a height of 500 s.d. 2,000 m asl. Only about $9 \%$ grow in the lowlands, and about $1 \%$ 
grow in highareas (Pferffe, 1995). The diversity of orchid species is higher at the altitude of 500 - 1,500 mdpl compared to the lower plains (Comber, 1990).

The Gebugan Nature Reserve area which relatively spacious and exposed by more sunlight causes a large number of epiphytic orchids to be found in the study sites. Epiphytic orchid life is influenced by the intensity of sunlight, the nature of life attached to other plants (epiphytes) is one way to adapt to get sunlight because the type of epiphytes requires higher light intensity (Tirta et al., 2010).

Based on environmental parameters that had been measured, the environmental condition of Gebugan Nature Reserve is suitable for the growth of orchids. Areas that have high humidity and relatively low temperatures allow the orchid plants to grow and develop very well (Hasanuddin, 2010). In mountainous areas, the number of orchids is much higher than in the lowlands because high mountain areas has higher humidity, lots of rainfall, lowtemperatures and moderate sunlight intensity (Sastrapradja, 1976).

The novelty of the research is found 11 species of epiphytic orchid and 1 species of terrestrial orchid which isa newdata base of orchid in the Gebugan Nature Reserve. The result of the study would be beneficial for developing strategy of genetic conservation of orchird germplasm. Study on flora result in initial data that support the conservation effort in biodiversity (Henri et al., 2017).

\section{CONCLUSION}

The species of orchids found in the Gebugan Nature Reserve as many as 12 species were included in 8 genera. A total of 11 species of orchids were epiphytic orchids and 1 species of terrestrial orchids. The abundance of orchid species was relatively higher in thehigher altitudes. Micropera sp was the highest abundance and $\mathrm{Co}^{-}$ rymborkis veratrifolia was the lowest abundance orchid.Gebugan Nature Reserve issuitable environment for orchid to grow.

\section{REFERENCES}

Badu(2013). Jenis-Jenis Pohon Inang Anggrek Alamdi sekitar Jalur Pendakian Shelter I-II Gunung Nokilalaki di Kawasan Taman Nasional Lore Lindu. Skripsi.Palu: Fakultas Kehutanan,Universitas Tadulako.

BKSDA Jawa Tengah. (2009). Buku Informasi Kawasan Konservasi. Semarang: Balai Konservasi Sum- ber Daya Jawa Tengah

Chikmawati, T.(1994). Studi biosistimatika Spathoglottis aurea dan $S$. plicata di Pulau Jawa. Thesis. Bogor: Sekolah Pascasarjana, Institut Pertanian Bogor.

Comber, J.B. (1990). Orchids of Java. London: Bentham-moxon Trust. Kew: The Royal Botanic Gardens.

Crain BJ. (2012). On the relationship between Bryophyte cover and the distribution of Lepanthes spp. Lankesteriana 12 (1): 13-18.

Dressler, R. L. (1982). The orchids natural history and classification. England: Harvard University Press. Cambridge, Massachusetts and London, 332p.

Destri, Fudola, A., Harto \& Kusnadi (2015). Survei Keanekaragaman Anggrek (Orchidaceae) di Kabupaten Bangka Tengah dan Belitung, Provinsi Kepulauan Bangka Belitung. PROSSEM NAS BIODIV INDON, 1 (3) : 509-514

Hasanuddin.(2010). Jenis Tumbuhan Anggrek Epifit di Kawasan Cagar Alam Jantho Kabupaten Aceh Besar. www.Jurnal Unsyah.ac.id. Diakses pada tanggal 20/09/2017

Henri, L. Haki and J. Batoro. (2017). The Potensial of Flora and Fauna as Tourist Attraction in Biodiversity Park of Pelawan Forest, Central Bangka. Biosaintifika 9 (2) : 240 - 247

Jacquemyn, H. Honnay, O. Pailler, T. (2007). Range size variation, nestedness and species turnover of orchid species along an altitudinal gradient on Reunion Island: Implication for conservation. Biological Conservation 136: 388397.

Kartikaningrum \& Suskandari. (2004). Panduan Karakterisasi Tanaman Hias: Anggrek dan Anthurium. Departemen Pertanian. Badan Penelitian dan Pengembangan Pertanian Komisi Nasional Plasma Nutfah.0-

Krebs, C.(1972). Ecology, the Experimental analysis of distribution and abundance.New York.Herper\& Row Publisher.

Martawijaya, A.I. Kartasujana.Y, I. Mandang.S, A, Prawira. K, \&Kadir. (1989). Atlas Kayu Indonesia Jilid II. Bogor: Pusat Penelitian dan Pengembangan Hasil Hutan.

Musa, F.F. Syamsuardi dan Arbain, A. (2013). Keanekaragaman Jenis Orchidaceae Di Kawasan Hutan Lindung Gunung Talang Sumatra Barat. Jurnal Biologi Universitas Andalas (J. Bio. UUA), 2(2): 153-160

Partomihardja, T. (1991). Kajian Komunitas Epifit di Hutan Dipterocarpaceae Lahan Pamah, Wanariset - Kalimantan Timur Sebelum Kebakaran Hutan. Media Konservasi Vol. III No. 3.h. 57-66. Bogor: Jurusan Konservasi Sumberdaya Hutan_Fakultas Kehutanan - IPB

Partomihardja, T. (2003). Colonization of orchids on the Krakatau Islands. Puslit Biologi-LIPI. Bogor. Indonesia. Telopea 10(1): 299-310.

Prastowo \& Roshetko.(2006).Tehnik Pembibitan dan Perbanyakan Vegetatif Tanaman

World Agroforestry Centre (ICRAF) dan Winrock In- 
Tria Farokhah, Sri Utami, Jumari / Biosaintifika 10 (2) (2018) 284-290

ternational. Bogor, Indonesia. p. 100.

Priandana, A. Y. (2007). Eksplorasi Anggrek Epifit di Kawasan Taman Hutan Raya R. Soeryo Sisi Timur Gunung Anjasmoro. Skripsi. Malang: Jurusan Budidaya Pertanian Fakultas Pertanian Universitas Brawijaya.

Puspitaningtyas, D. M. (2005). Studi Keragaman Anggrek di Cagar Alam Gunung Simpang, Jawa Barat. Bogor: UPT Balai Pengembangan Kebun Raya-LIPI. Biodiversitas 6(2):103-107

Puspitaningtyas. (2007). Inventarisasi Anggrek dan Inangnya di Taman Nasional Meru Betiri Jawa Timur.Biodiversitas Vol. 8, No. 3 Hal: 210- 214.

Sastrapradja, S. (1976). Buku Anggrek Indonesia. Bogor: Lembaga Biologi Nasional-LIPI.

Sutiyoso, Y. \& B. Sarwono. (2009). Merawat Anggrek.
Jakarta: PT Penebar swadaya.

Tahier, S,S. Haryani T,S,. \&Wiedarti S. (2012). Keanekaragaman Anggrek di Cagar Alam dan Taman Wisata Alam Telaga Warna, Puncak, Bogor. ejournal.unpak.ac.id. Diakses pada tanggal 20/09/2017

Tirta, I.G,. Lugrayasa I.N\&Irawati. (2010). Studi Anggrek Epifit Pada Tiga Lokasi di Kabupaten Malinau, Kalimantan Timur Kecamatan Timur. Buletin Kebun Raya Vol. 13 No 1, Januari 2010

Whitner, C.L. 1974. The Orchids: Scientific Studies. A Wiley-Interscience Publication.John Wiley \& Sons, New York-London-Sydney-Toronto.

Yulia, N. D. (2010). Evaluasi Keragaman Anggrek di Tiga Kawasan Hutan Alam Jawa Timur. UPT Balai Konservasi Tumbuhan Kebun Raya Purwodadi, LIPI, Pasuruan. 